\title{
Untimely Matter
}

in the Time of Shakespeare 
This page intentionally left blank 


\section{Untimely Matter \\ in the Time of \\ Shakespeare}

Jonathan Gil Harris

$\overline{\text { PENN }}$

University of Pennsyluania Press

Philadelphia 
Copyright (C) 2009 University of Pennsylvania Press

All rights reserved. Except for brief quotations used for purposes of review or scholarly citation, none of this book may be reproduced in any form by any means without written permission from the publisher.

Published by

University of Pennsylvania Press

Philadelphia, Pennsylvania 19104-4II2

Printed in the United States of America on acid-free paper

IO $\quad 9 \begin{array}{lllllllll} & 8 & 7 & 6 & 5 & 4 & 3 & 2 & \text { I }\end{array}$

Library of Congress Cataloging-in-Publication Data

Harris, Jonathan Gil.

Untimely matter in the time of Shakespeare / Jonathan Gil Harris.

p. $\mathrm{cm}$.

Includes bibliographical references and index.

ISBN 978-0-8I22-4II8-I (acid-free paper)

I. English literature-Early modern, I500-I700-History and criticism-Theory, etc. 2.

Literature and history-Great Britain-History. 3. Literature and society-Great

Britain-History. 4. Great Britain-History-1066-I687-Historiography. I. Title.

$\mathrm{PR}_{421 . \mathrm{H}_{2} 6} 2009$

$820.9^{\prime} 003-\mathrm{dc} 22$ 
To Madhavi Menon,

because it's about time 
This page intentionally left blank 